\title{
Pearl Millet and Sorghum Yield Response to Fertilizer in the Sahel of Burkina Faso
}

\author{
Idriss Serme (Corresponding author) \\ Institut de l'Environnement et de Recherches Agricoles (INERA), \\ O4 BP 8645 Ouagadougou. E-mail: sermeidriss@yahoo.fr
}

Korodjouma Ouattara \& Alimata Arzouma Bandaogo

Institut de l'Environnement et de Recherches Agricoles (INERA),

O4 BP 8645 Ouagadougou.

\begin{abstract}
Charles Wortmann
Department of Agronomy and Horticulture, University of Nebraska-Lincoln, Lincoln NE, USA.
\end{abstract}

Received: January 2, 2018

Accepted: January 23, 2018

doi:10.5296/jas.v6i1.12384

URL: https://doi.org/10.5296/jas.v6i1.12384

\begin{abstract}
Sorghum (Sorghum bicolor L. Moench) and pearl millet (Pennisetum glaucum (L.) R. Br.) were domesticated in Africa for human consumption and are often the dominant cereals in semi-arid areas where yield is constrained by soil water deficits, nutrient deficiencies, and other constraints. Research was conducted to quantify yield responses and profitability of sorghum and pearl millet produced in the Sahel of Burkina Faso to fertilizer N, P, K, and a $\mathrm{Mg}-\mathrm{S}-\mathrm{Zn}-\mathrm{B}$ diagnostic treatment. Mean yields across trials were 1.2 and $0.9 \mathrm{Mg} \mathrm{ha}^{-1}$ for pearl millet and sorghum, respectively. The effects of $\mathrm{N}, \mathrm{K}$, the diagnostic treatment, and interactions were not significant for both pearl millet and sorghum. There was a mean curvilinear to plateau response to $\mathrm{P}$ for pearl millet and a linear response to $\mathrm{P}$ for sorghum. The economical optimal $P$ rates for pearl millet were modest, ranging from 6 to $33 \mathrm{~kg} \mathrm{ha}^{-1}$ at $100 \%$ of the rate to maximize net returns per ha to $\mathrm{P}$ application when the cost of using fertilizer $P$ was high and low, respectively, relative to the grain price (Table 4). The application of $\mathrm{P}$ for pearl millet had high profit potential even with a high cost $\mathrm{P}$ use scenario.
\end{abstract}


For sorghum production, $\mathrm{P}$ application was not profitable if the cost per $\mathrm{kg}$ of fertilizer $\mathrm{P}$ use exceeded the value of $9 \mathrm{~kg}$ of sorghum grain. The results, therefore, indicate a high and low profit potential for $\mathrm{P}$ applied for pearl millet and sorghum, respectively, in the Sahel of Burkina Faso.

Keywords: Agronomic efficiency; profitability; fertilizer, response function; yield.

Abbreviations: AE, agronomy efficiency; EOR, economically optimal rate; PCR, profit cost ratio;

\section{Introduction}

Sorghum (Sorghum bicolor L. Moench) and pearl millet (Pennisetum glaucum (L.) R. Br.) were domesticated in north eastern and western Africa, respectively, and continue to be important as cereal crops. The estimated global area of sorghum and pearl millet is 64.2 million ha $\mathrm{yr}^{-1}$ with approximately $60 \%$ of the production area in West Africa (FAO, 2014). Sorghum is ranked second and pearl millet third for area of production in Africa.

In West Africa, sorghum and pearl millet are grown in semi-arid to arid zones where soils predominately have sandy textures, low organic matter content, and low nutrient availability (Mason et al., 2015). Rainfall is limited and erratic, air and soil temperatures are high, and the growing season length is short and varies greatly across years. Pearl millet and sorghum are grown in Africa primarily for grain used for human consumption, but the stover is also of great economic importance for livestock feed, building materials and fuel. Average pearl millet and sorghum yields worldwide are lower than for other cereal crops due to production in relative stressful environments (Wortmann et al., 2009; FAO, 2014), but improved production practices and cultivars result in more efficient use of photosynthetically active radiation, water, and nutrients, and greatly increased grain and stover yields.

The combined use of improved seed, irrigation and fertilizer enabled the Green Revolution of Latin America and Asia (Bationo et al., 2008). Adequate use of fertilizer with high partial factor productivity will be essential to improved food security in sub-Saharan Africa (SSA) where average fertilizer application is around $10 \mathrm{~kg} \mathrm{ha}^{-1}$ and less than for any other agricultural region in the world (Henao and Baanante, 2006; Hernandez and Torero, 2011). The reasons for the dismal fertilizer use intensity in SSA are many and varied, and could be analyzed with respect to response rate and effectiveness, profitability and efficiency, and sustainability of fertilizer use (Dittoh et al., 2012).

Dittoh et al. (2012) reported that fertilizer's full agronomic potential is often unrealized because of poor soil fertility caused by mismanagement of fertilizer at the farm level, failure of extension service to inform farmers about appropriate technology, poor availability of fertilizer, and lack of complementary inputs. The use of organic inputs such as crop residues, manure and compost improves the physical, chemical and microbiological properties of the soil as well as nutrient supply and therefore contributes to sustainable crop production (Satyanarayana et al., 2002). Consequently, practices which maintain or increase soil organic matter must be adopted to achieve a sustained productive agriculture (Melenya et al., 2015). 


\section{Macrothink Institute ${ }^{\mathrm{TM}}$}

Deficiencies of $\mathrm{N}$ and $\mathrm{P}$ are important constraints to pearl millet and sorghum yield (Hien et al., 1992; Mason et al., 2015). Fertilizer recommendations in Burkina Faso are primarily based on fertilizer trials conducted during the 1970s. The last update of fertilizers recommendation in Burkina Faso was done in 1992 and was based on agro-ecological zones and plant requirements by Institut de l'Environement et de Recherches Agricoles (INERA) under a project called "Projet Engrais Vivriers" (Hien et al., 1992). Growing conditions and management practices have changed since the update of fertilizer use recommendations. In the meantime, cropland has had a negative nutrient balance indicating mining of soils which could imply non-sustainable crop production (Bationo et al., 2008). Additional soil testing and fertilizer trials are needed to develop sound crop and area-specific recommendations. Therefore, field research was conducted to determine nutrient response for sorghum and pearl millet production in the Sahel with and without manure applied.

Our working hypothesis was that sorghum and pearl millet significantly respond to cattle manure and mineral fertilizer. The objectives of the study were to: (i) to assess sorghum and pearl millet yield response to fertilizer $\mathrm{N}, \mathrm{P}$ and $\mathrm{K}$ with and without manure application; (ii) and to determine the agronomic efficiency and economic returns to N, P and K application.

\section{Materials and Methods}

\subsection{Site Description4}

The study was carried out in 2014 and in 2015 at the INERA experimental field located near Dori and in six neighboring farmer's fields in the Sahel of northern Burkina Faso. The erratic unimodal rainfall, typically between 400 and $600 \mathrm{~mm} \mathrm{yr}^{-1}$, occurs from June to October with about 54 rainy days (Fig. 1).

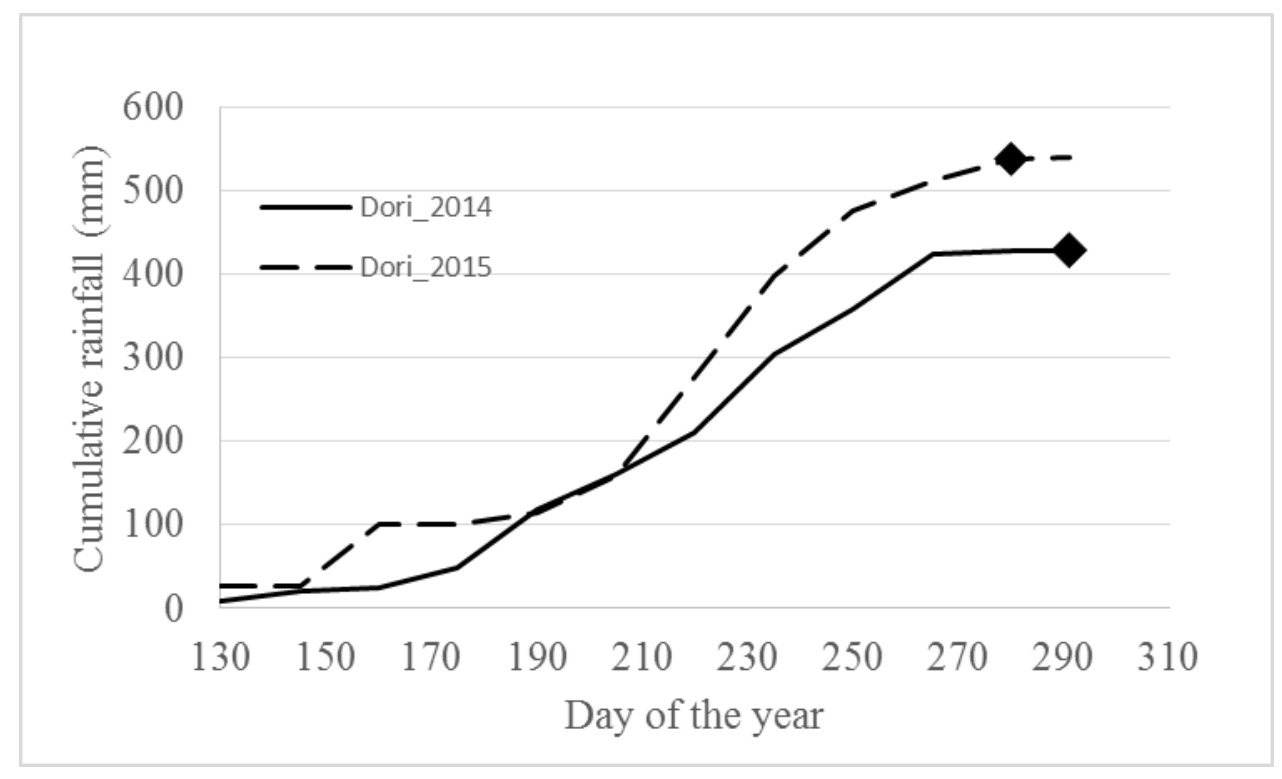

Figure1. Cumulative rainfall in Dori (Burkina Faso). 


\section{Macrothink}

Journal of Agricultural Studies

ISSN 2166-0379

2018, Vol. 6, No. 1

The soils were classified as Arenosols (WRB 2006). Soil samples for the 0-20 cm depth were collected for each replicate before any fertilizer application and analyzed for physical and chemical properties (Table 1). The air-dried samples were sent to the World Agroforestry Center Soil-Plant Spectral Diagnostic Laboratory in Nairobi, Kenya https://www.worldagroforestry.org/sd/landhealth/soil-plant-spectral-diagnostics-laboratory/so ps. The analysis was with mid-infrared spectral analysis, complemented by wet chemistry analysis of about $10 \%$ of the samples for calibration of the spectral analysis (Shepherd and Walsh, 2007; Terhoeven-Urselmans et al., 2010; Towett et al., 2015). Organic C and N were determined with a Thermal Scientific Flash 2000. Soil pH was measured with a 1:2.5 soil: water slurry. The nutrient extraction was by Mehlich 3 (Mehlich, 1984). A Horiba LA 950 Laser Scattering Particle Size Distribution Analyzer was used for determination of particle size distribution. The soil was acidic with a $\mathrm{pH}\left(\mathrm{H}_{2} \mathrm{O}\right)$ of 5.5 and had low organic $\mathrm{N}$ and Mehlich-3 P, and very low organic C (Table 1). The soil was a silt loam at $0-0.2 \mathrm{~m}$ depth.

Table 1. Soil properties for 0 to $0.2 \mathrm{~m}$ depth at INERA's research station in Dori, Burkina Faso

\begin{tabular}{ll}
\hline Soil properties & Mean values \\
\hline $\mathrm{pH}\left(1: 2.5 \mathrm{H}_{2} \mathrm{O}\right)$ & 5.5 \\
Organic $\mathrm{C}\left(\mathrm{g} \mathrm{kg}^{-1}\right)$ & 2.3 \\
Total $\mathrm{N}\left(\mathrm{g} \mathrm{kg}^{-1}\right)$ & 0.2 \\
Mehlich-3 $\mathrm{P}\left(\mathrm{mg} \mathrm{kg}^{-1}\right)$ & 11.1 \\
\hline Exchangeable bases $\left(\mathrm{cmol}^{(+)} \mathbf{k g}^{-1}\right)$ & \\
$\mathrm{Ca}$ & 2.22 \\
$\mathrm{Mg}$ & 0.78 \\
$\mathrm{~K}$ & 0.20 \\
$\mathrm{Na}$ & 0.14 \\
\hline Sum of anions $(\mathrm{S})$ & 1.58 \\
Cation exchange capacity $(\mathrm{CEC})(\mathrm{cmol} \mathrm{kg})$ & 5.80 \\
Saturation rate $(\mathrm{S} / \mathrm{CEC})(\%)$ & 27.00 \\
\hline Particle size distribution $\left(\mathrm{g} \mathrm{kg}{ }^{-1}\right)$ & \\
Sand & 600 \\
Silt & 128 \\
Clay & 260 \\
Texture & Sandy loam \\
\hline
\end{tabular}




\subsection{Experimental Design and Treatments}

The experiments had a randomized complete block design (RCBD) with three replicates on station and one replicate in each of six farmers' fields for the on-farm trial both for sorghum and pearl millet. The 16 treatments allowed for evaluation of: five levels of $\mathrm{N}$ in $20 \mathrm{~kg} \mathrm{ha}^{-1}$ increments, with 0 and $15 \mathrm{~kg} \mathrm{ha}^{-1} \mathrm{P}$ uniformly applied; four levels of $\mathrm{P}$ in increments of 7.5 $\mathrm{kg} \mathrm{ha}{ }^{-1}$; four levels of $\mathrm{K}$ in increments of $10 \mathrm{~kg} \mathrm{ha}^{-1}$; and a treatment for diagnosis of $\mathrm{Mg}-\mathrm{S}-\mathrm{Zn}-\mathrm{B}$ deficiencies (Table 2). The plots sizes were $24 \mathrm{~m}^{2}(6 \mathrm{~m} \times 4 \mathrm{~m})$. The fertilizers applied were urea $(46 \% \mathrm{~N})$, triple super phosphate $\left(45 \% \mathrm{P}_{2} \mathrm{O}_{5}\right)$, murate of potash $(60.8 \%$ $\left.\mathrm{K}_{2} \mathrm{O}\right)$, kieserite $\left(\mathrm{MgSO}_{4}\right.$ with $15 \% \mathrm{MgO}$ and $\left.22 \% \mathrm{~S}\right)$, borax-pentahydrate $\left(48 \% \mathrm{~B}_{2} \mathrm{O}_{3}\right)$ and zinc sulphate $\left(\mathrm{ZnSO}_{4} 36.8 \%\right)$.

Table 2. Nutrient rate treatments (T) for pearl millet and sorghum nutrient response trials conducted in the Sahel of Burkina Faso.

\begin{tabular}{|c|c|c|c|}
\hline $\mathrm{T}$ & N-P-K & $\mathrm{T}$ & N-P-K \\
\hline 1 & $0-0-0$ & 9 & $60-15-0$ \\
\hline 2 & $20-0-0$ & 10 & $80-15-0$ \\
\hline 3 & $40-0-0$ & 11 & $60-7.5-0$ \\
\hline 4 & $60-0-0$ & 12 & $60-22.5-0$ \\
\hline 5 & $80-0-0$ & 13 & $60-15-10$ \\
\hline 6 & $0-15-0$ & 14 & $60-15-20$ \\
\hline 7 & $20-15-0$ & 15 & $60-15-30$ \\
\hline 8 & $40-15-0$ & 16 & $60-15-20-D$ \\
\hline
\end{tabular}

The nutrient rate $\left(\mathrm{kg} \mathrm{ha}^{-1}\right)$ treatments refer to: N-P-K and the diagnostic treatment with N-P-K-S-Zn-Mg-B (D). 


\subsection{Crop Management}

The field was ploughed and harrowed. The crop varieties used were SOSSAT C88 (90 days to maturity) for pearl millet and Kapelga (105 days to maturity) for sorghum. The pearl millet was sowed with four seeds per hill at a hill spacing of $1.0 \times 0.8 \mathrm{~m}$ while the sorghum hill spacing was $0.8 \times 0.4 \mathrm{~m}$. In 2014, the crops were sown on July 29 and harvested on Nov 12 while in 2015, sowing was on July 28 and harvest on Nov 11. The seedlings were thinned to two per hill one week after germination. The various fertilizer treatments were point applied at about $50 \mathrm{~mm}$ from plant stands and covered with soil two weeks after planting. During the growing period, the plots were manually weeded twice with hoes.

At physiological maturity, the crops were harvested in the delineated area of $14.56 \mathrm{~m}^{2}$ in the middle of each treatment plot skipping the border rows. After sun drying the panicles, the grain was removed by threshing, and further dried to a water content of $130 \mathrm{~g} \mathrm{~kg}^{-1}$. The dried grain weight per plot was used to calculate yield $\left(\mathrm{Mg} \mathrm{ha}^{-1}\right)$.

\subsection{Data Analysis}

Treatment effects on yield were determined by analysis of variance (ANOVA) combined across site-years using Statistix 10 (Analytical Software, Tallahassee, FL) with effects considered significant at $\mathrm{P}<0.05$. The effect of $\mathrm{N}$ and $\mathrm{P}$ rate and their interactions were evaluated by conducting a separate ANOVA for the sub-set of $10 \mathrm{~N}$ rate treatments with 0 and $15 \mathrm{~kg} \mathrm{ha}^{-1} \mathrm{P}$ applied. When the $\mathrm{N}$ rate by $\mathrm{P}$ rate interaction was not significant, further analysis of the response to $\mathrm{N}$ rate was done with $\mathrm{N}$ rate effects averaged across $\mathrm{P}$ rates. The effects of $\mathrm{P}$ and $\mathrm{K}$ rates and of the diagnostic treatment were tested using linear contrasts. When the effects of $\mathrm{N}, \mathrm{K}$ and the diagnostic treatment were determined to be not significant, further analysis was done for $\mathrm{P}$ effects only. The $\mathrm{P}$ rate effect for pearl millet was fitted to a curvilinear-plateau response with an asymptotic regression function given as yield $\left(\mathrm{Mg} \mathrm{ha}^{-1}\right)$ $\mathrm{y}=a-b c^{P}$, where $a$ was yield at the plateau (i.e. expected maximum), $b$ was the amplitude (the gain in yield due to nutrient application), $c$ was a curvature coefficient and $P$ was the $\mathrm{P}$ rate. The $\mathrm{P}$ rate effect for sorghum was linear.

The $\mathrm{P}$ use efficiency by pearl millet was assessed as agronomic efficiency which was calculated as the ratio of the increased crop output to the amount of $\mathrm{P}$ applied $\left(\mathrm{kg} \mathrm{kg}^{-1}\right)$. The economically optimal rates $(\mathrm{EOR})$ were determined for $\mathrm{P}$ use costs relative to grain value $(\mathrm{kg}$ $\mathrm{kg}^{-1}$ ) with $3,6,9,12,15$ and $18 \mathrm{~kg}$ of grain equal to cost of applying one $\mathrm{kg}$ of nutrient. The agronomic efficiency (AE) was the average gain in the value of crop output per $\mathrm{kg}$ of $\mathrm{P}$ applied $\left(\mathrm{kg} \mathrm{kg}^{-1}\right)$. The profit to cost ratio (PCR) was used to evaluate returns to P use. Hence, PCR was calculated as a ratio of value of increased crop output minus the cost of $\mathrm{P}$ use with this difference then divided by cost of $\mathrm{P}$ use $\left(\$ \$^{-1}\right)$. Technically, PCR $=1$ means that $\$ 1$ investment in P application results in $\$ 1$ added profit. CIMMYT (1988) suggested that PCR $\geq 1$ was required to attract much smallholder investment. 


\section{MInstitute"}

\section{Results}

The overall mean yields were $1.2 \mathrm{Mg} \mathrm{ha}^{-1}$ for pearl millet and $0.90 \mathrm{Mg} \mathrm{ha}^{-1}$ for sorghum. All effects of $\mathrm{N}$ rate, $\mathrm{K}$ rate, the diagnostic treatment, and interactions were not significant for pearl millet and for sorghum. There was a curvilinear response of pearl millet and a linear response of sorghum to $\mathrm{P}$ across the two years (Table 3; Fig. 2). Depending on the cost of $\mathrm{P}$ use relative to grain value, the EOR for P ranged from 6 to $33 \mathrm{~kg} \mathrm{ha}^{-1}$ for pearl millet. Given the linear response of sorghum, the EOR of $\mathrm{P}$ was assumed to be $22.5 \mathrm{~kg} \mathrm{ha}^{-1}$ unless fertilizer $\mathrm{P}$ use cost was too great to be profitable.

Pearl millet response to $\mathrm{P}$ was profitable even when the cost of $\mathrm{P}$ use per $\mathrm{kg}$ was equal to the value of $18 \mathrm{~kg}$ grain. The yield increase at EOR for $\mathrm{P}$ ranged from 0.37 to $0.50 \mathrm{Mg} \mathrm{ha}{ }^{-1}$ (Table 4). The AE for $\mathrm{P}$ at EOR ranged from 15.1 to $61.5 \mathrm{~kg} \mathrm{~kg}^{-1}$. The yield increase at $50 \%$ EOR for P ranged from 0.24 to $0.48 \mathrm{Mg} \mathrm{ha}^{-1}$. The AE for $\mathrm{P}$ at $50 \%$ EOR ranged from 29.2 to $81.3 \mathrm{~kg} \mathrm{~kg}^{-1}$. The PCR of P ranged from 2.42 to $4.05 \$ \$^{-1}$ and 3.52 to $8.75 \$ \$^{-1}$, respectively, at $100 \%$ and $50 \%$ EOR. If P fertilizer was applied at $50 \%$ of EOR over two ha rather than at $100 \%$ EOR over one ha, as financially constrained farmers might do, the gain in pearl millet grain production, AE and PCR would be increased by $54 \%, 43 \%$, and $71 \%$, respectively.

For sorghum, the AE of P application was $20 \mathrm{~kg} \mathrm{~kg}^{-1}$ with the highest $\mathrm{P}$ rate of $22.5 \mathrm{~kg} \mathrm{ha}^{-1}$ (Table 3). The PCR with the application of $22.5 \mathrm{~kg}$ ha of $\mathrm{P}$ were 5.66, 2.33, 1.22, and 0.67 respectively for when the cost of fertilizer $P$ use is equal to the values of $3,6,9$, and $12 \mathrm{~kg}$ of grain (Table 5). The application of $\mathrm{P}$ was not profitable when the price of $1 \mathrm{~kg}$ of $\mathrm{P}$ was equal to the value of $>12 \mathrm{~kg}$ of sorghum grain.

Table 3. The P rate effects on rainfed pearl millet and sorghum grain yield and response coefficients, in the Sahel of Burkina Faso

\begin{tabular}{lcc}
\hline P rate & Pearl millet & Sorghum \\
\hline kg ha $^{-1}$ & \multicolumn{2}{c}{$\mathbf{M g ~ h a}^{-1}$} \\
\hline 0 & 0.83 & 0.68 \\
7.5 & 1.19 & 0.85 \\
15 & 1.43 & 1.02 \\
22.5 & 1.25 & 1.18 \\
$a_{\dagger}^{\dagger}$ & 1.34 & 0.68 \\
$b$ & 0.5 & 0.02 \\
$c$ & 0.8 & \\
\hline
\end{tabular}

$\dagger$ Grain yield responses to $\mathrm{P}$ rate was curvilinear to plateau for pearl millet ( $\mathrm{Y}=\mathrm{a}-\mathrm{bcr}$ with $\mathrm{r}$ $=\mathrm{P}$ rate) and linear for sorghum. 


\section{Macrothink}

Table 4. The effect of nutrient application at $100 \%$ compared with $50 \%$ of the economically optimal rate (EOR) on pearl millet yield increase, agronomic efficiency of $\mathrm{P}$ use (AE), and profit to cost ratio (PCR) of P use for rainfed pearl millet in the Sahel of Burkina Faso.

\begin{tabular}{|c|c|c|c|c|}
\hline $\mathbf{C P} \dagger$ & EOR & Yield increase & $\mathbf{A E}$ & PCR \\
\hline $\mathrm{kg} \mathrm{ha}^{-1}$ & $\mathrm{~kg} \mathrm{ha}^{-1}$ & $\mathrm{~kg} \mathrm{ha}^{-1}$ & $\mathrm{~kg} \mathrm{ha}^{-1}$ & $\$ \$^{-1}$ \\
\hline \multicolumn{5}{|c|}{ Application at $100 \%$ EOR } \\
\hline 3 & 33.0 & 500 & 15.1 & 4.05 \\
\hline 6 & 16.0 & 486 & 30.4 & 4.06 \\
\hline 9 & 11.0 & 457 & 41.6 & 3.62 \\
\hline 12 & 8.0 & 416 & 52.0 & 3.33 \\
\hline 15 & 7.0 & 395 & 56.4 & 2.76 \\
\hline 18 & 6.0 & 369 & 61.5 & 2.42 \\
\hline
\end{tabular}

\section{Application at 50\% EOR}


12

15

18
4.0

3.5

3.0
295

244

244
69.7

3.65

73.8

5.15

81.3

$\dagger$ The results are in consideration of the cost of nutrient use per kg relative to the value of one $\mathrm{kg}$ of rice grain $(\mathrm{CP})$.

Table 5. The profit to cost ratio (PCR) for rainfed sorghum response to $22.5 \mathrm{~kg} \mathrm{ha}^{-1} \mathrm{P}$ in the Sahel of Burkina Faso

\begin{tabular}{ll}
\hline $\mathrm{CP}$ & $\mathrm{PCR}$ \\
\hline $\mathbf{k g ~ h a}^{\mathbf{- 1}}$ & $\mathbf{\$} \mathbf{\$}^{-\mathbf{1}}$ \\
3 & 5.67 \\
6 & 2.33 \\
9 & 1.22 \\
12 & 0.67 \\
\hline
\end{tabular}

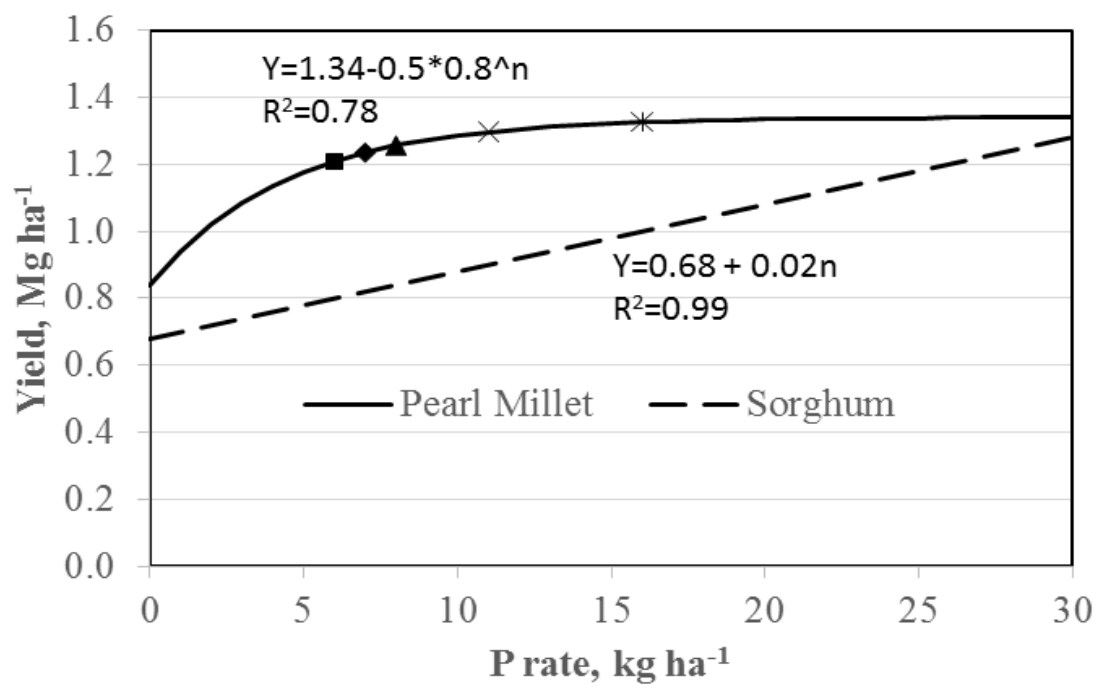

Figure 2. Pearl millet and sorghum grain yield responses to applied $\mathrm{P}$ in the Sahel of Burkina Faso when the cost of nutrient use is equal to the value of $3(\bullet), 6(*), 9(\times), 12(\boldsymbol{\Delta}), 15(\bullet)$ or $18(\mathbf{\square}) \mathrm{kg}$ of pearl millet grain. 


\section{Discussion}

In tropical soils, SOM is a major determinate of soil productivity (Bationo et al., 2008). The low sorghum and pearl millet yields were not unexpected for the water stress production conditions typical to the Sahel agroecological zone. The average pearl millet grain yield was above $1 \mathrm{Mg} \mathrm{ha}^{-1}$ and above the yield of sorghum due to its better adaptation to the harsh production conditions of the Sahel.

There was no response of pearl millet and sorghum to $\mathrm{N}$ application across the two years. Considering a critical value of $<30 \mathrm{~g} \mathrm{~kg}^{-1} \mathrm{SOM}$ for a probable response to applied $\mathrm{N}$ (Foster, 1971), the soils in the Sahel had a very low SOM content $\left(\mathrm{g} \mathrm{kg}^{-1}\right)$. While soil $\mathrm{N}$ availability was likely low, other factors were more limiting to crop growth and therefore to response to $\mathrm{N}$. These results were not in agreement with the pearl millet results reported previously by Bagayogo et al. (2011), Bationo et. (2008), and Maman et al. (2017) which fitted a curvilinear to plateau responses to $\mathrm{N}$ application but even for these results, the mean yield increase due to $\mathrm{N}$ application was only about $0.1 \mathrm{Mg} \mathrm{ha}^{-1}$. Kaizzi et al. (2012) reported a curvilinear response of sorghum to $\mathrm{N}$ but the yields and yield increases were much higher than achieved for the current study.

The pearl millet and sorghum grain responses to $\mathrm{P}$ application were respectively curvilinear to plateau and linear. This response to $\mathrm{P}$ application could be explained by the very low value of the Mehlich-3 P in the Sahel of Burkina Faso. These results are consistent with those obtained by Muehlig-Versen et al. (2003), who reported 72 to $88 \%$ yield increase with 3 to 7 $\mathrm{kg} \mathrm{ha}^{-1} \mathrm{P}$ placed near pearl millet plants. Maman et al. $(2017 \mathrm{a}, \mathrm{b})$ reported relatively great response to $\mathrm{P}$ compared with $\mathrm{N}$ for pearl millet and sorghum. Kaizzi et al. (2012) reported a positive response of sorghum to $\mathrm{P}$ when $\mathrm{N}$ is applied. However, the linear response of sorghum to $\mathrm{P}$, with a low $\mathrm{AE}$ of $22 \mathrm{~kg} \mathrm{~kg}^{-1}$, rather than a curvilinear response was unexplained. The response indicates inefficient recovery of $\mathrm{P}$ although the soil properties were not indicative of high $\mathrm{P}$ adsorption rates compared to what would be expected with lower $\mathrm{pH}$ and higher clay soils.

The diagnostic treatment did not affect pearl millet and sorghum grain yields. The soil test $\mathrm{K}$ value was very low but no $\mathrm{K}$ effect on pearl millet and sorghum grain yield was observed. These lacks of responses indicate adequate availability of $\mathrm{K}, \mathrm{Mg}, \mathrm{S}, \mathrm{Zn}$, and $\mathrm{B}$ for production under such low yield conditions. The lack of response to $\mathrm{K}$ is agreement with Hien et al. (1992). Once other more limiting constraints are mitigated, response to one or more of these nutrients may occur. These results are consistent with those obtained by Maman et al. (2017a, b) for sorghum and pearl millet production in the Sahel.

Profit considerations are very important to farmer decision making and especially for smallholders who are very constrained financially but account for most agricultural production in the Sahel. Such farmers need PCR $>1$ for an investment to compete with other uses of available finance (CIMMYT, 1988). The EOR of $\mathrm{P}$ for pearl millet ranged from 6 to $33 \mathrm{~kg} \mathrm{ha}^{-1}$ at $100 \%$ EOR when the cost of using fertilizer P was high and low, respectively, relative to the grain price (Table 4). The application of $\mathrm{P}$ for pearl millet is very profitable even when $\mathrm{P}$ fertilizer use cost was equal to the value of $18 \mathrm{~kg}$ of grain. Application of $\mathrm{P}$ at 
$50 \%$ compared with $100 \%$ of EOR for pearl millet improved the PCR by $71 \%$ which gives an opportunity to resource-poor farmers to increase profit from a constrained investment in fertilizer. For sorghum production, $\mathrm{P}$ application was not adequately profitable for poor smallholders if fertilizer $\mathrm{P}$ use cost per $\mathrm{kg}$ is greater than the value of $9 \mathrm{~kg}$ grain. The results indicate that financially constrained farmers need to consider $\mathrm{P}$ fertilizer use for sorghum production very carefully relative to alternative uses of available finance such as fertilizer use for pearl millet in the Sahel.

\section{Conclusion}

The results indicate that $\mathrm{K}, \mathrm{Mg}, \mathrm{S}, \mathrm{Zn}$, and $\mathrm{B}$ deficiencies are not constraining sorghum and pearl millet yield in the Sahel of Burkina Faso. Nutrient response functions for pearl millet and sorghum in the Sahel of Burkina Faso indicate profit potential from applied P. However, the indicated profit potential under sorghum production is not likely to be attractive to financially constrained farmers unless fertilizer $\mathrm{P}$ use costs are low relative to farmgate sorghum grain value. The results indicated that net returns per investment are $71 \%$ greater with 50\% compared with $100 \%$ EOR for P applied to pearl millet. The lack of response to N for both sorghum and pearl millet suggests that, unless other research results indicate otherwise, fertilizer $\mathrm{N}$ application does not have much profit potential for sorghum and pearl millet production in the Sahel of Burkina Faso.

\section{References}

Bagayoko, M., Maman, N., Palé, S., Sirifi, S., Taonda, S. J. B., Traore, S., \& Mason, S. C. (2011). Microdose and $\mathrm{N}$ and $\mathrm{P}$ fertilizer application rates for pearl millet in West Africa. Afr. J. Agric. Res. 6:1141-1150.

Bationo, A. (2008). Integrated soil fertility management options for agricultural intensification in the Sudano-Sahelian Zone of West Africa (p. 114). Nairobi: Academy Science Publishers.

CIMMYT Economics Program. (1988). From agronomic data to farmer recommendations: an economics training manual (No. 27). CIMMYT.

Dittoh, S., Omotosho, O., Belemvire, A., Akuriba, M., \& Haider, K. (2012). Supporting policy research to inform agricultural policy in Sub-Saharan Africa and South Asia. Improving the effectiveness, efficiency and sustainability of fertilizer use in Sub-Saharan Africa. Briefing Paper.

FAO (2014). World Reference Base for Soil Resources 2014. International soil classification system for naming soils and creating legends for soil maps. World Soil Resources Reports, (106).

Foster, H. L. (1971). Rapid routine soil and plant analysis without automatic equipment: I. Routine soil analysis. East Afr. Agric. For. J. 37:160-170

Henao, J., \& Baanante, C. (2006). "Agricultural production and soil nutrient mining in Africa: implications for resource conservation and policy development," IFDC- An International 
Center for Soil Fertility and Agricultural Development.

Hernandez, M., \& Torero, M. (2011). Fertilizer Market Situation. Market Structure, Consumption and Trade Patterns, and Pricing Behavior. Washington, DC: International Food Policy Research Institute (IFPRI).

Hien, V., Youl, S., Sanou, K., Traoré, O., \& Kabore, D. (1992). Rapport de synthese des activites du volet experimentation du Projet Engrais Vivrier, 1986-1991. Resultats agronomiques et evaluations economiques des formules d'engrais a moindre cout pour les cereales. Ouagadougou, Burkina Faso: INERA.

Kaizzi, K. C., Byalebeka, J., Semalulu, O., Alou, I., Zimwanguyizza, W., Nansamba, A., \& Wortmann, C. S. (2012). Sorghum response to fertilizer and nitrogen use efficiency in Uganda. Agron J 104:83-90. https://doi.org/10.2134/agronj2011.0182

Maman, N., Dicko, M., Abdou, G., Kouyate, Z., \& Wortmann, C. (2017a). Pearl millet and cowpea intercrop response to applied nutrients in West Africa. Agron. J. 109:2333-2342. https://doi.org/10.2134/agronj2017.03.0139

Maman, N., Dicko, M., Abdou, G., \& Wortmann, C. (2017b) Sorghum and groundnut sole and intercrop nutrient response in semi-arid West Africa. Agron. J. 109:1-11. https://doi.org/10.2134/agronj2017.02.0120

Mason, S. C., Maman, N., \& Pale, S. (2015). Pearl millet production practices in semi-arid West Africa: a review. Exp. Agric. 51(4):501-521.

https://doi.org/10.1017/S0014479714000441

Mehlich, A. (1984). Mehlich-3 soil test extractant: a modification of Mehlich-2 extractant. Commun. Soil. Sci. Plant Anal. 15:1409-1416. https://doi.org/10.1080/00103628409367568

Melenya, C., Logah, V., Aryee, D., Abubakari, A., Tuffour, H. O., \& Yeboah, I. B. (2015). Sorption of phosphorus in soils in the semi deciduous forest zone of Ghana. Appl. Res. J. 1:169-175.

Satyanarayana, V., Vara Prasad, P., Murthy, V., \& Boote, K. (2002). Influence of integrated use of farmyard manure and inorganic fertilizers on yield and yield components of irrigated lowland rice. J. Plant Nutr. 25:2081-2090.

https://doi.org/10.1081/PLN-120014062

Muehlig-Versen, B., Buerkert, A., Bationo, A., \& Roemheld, V. (2003). Phosphorus placement on acid arenosols of the West African Sahel. Exp. Agric. 39:307-325. https://doi.org/10.1017/S0014479703001261

Shepherd, K. D., \& Walsh, M. G. (2007). Infrared spectroscopy - enabling an evidence-based diagnostic surveillance approach to agricultural and environmental management in developing countries. J. Near Infrared Spectrosc. 15:1-19.

https://doi.org/10.1255/jnirs.716

Terhoeven-Urselmans, T., Vagen, T. G., Spaargaren, O., \& Shepherd, K. D. (2010). Prediction 


\section{Macrothink}

Journal of Agricultural Studies

ISSN 2166-0379 2018, Vol. 6, No. 1

of soil fertility properties from a globally distributed soil mid-infrared spectral library. Soil Sci. Soc. Am. J. 74:1792-1799. https://doi.org/10.2136/sssaj2009.0218

Towett, E. K., Shepherd, K. D., Sila, A., Aynekulu, E., \& Cadisch, G. (2015). Mid-infrared and total x-ray fluorescence spectroscopy complementarity for assessment of soil properties. Soil Sci. Soc. Am. J 79:1375-1385. https://doi.org/10.2136/sssaj2014.11.0458

Wortmann, C. S., Mamo, M., Mburu, C., Letayo, E., Abebe, G., Kayuki, K. C., Chisi, M., Mativavarira, M., Xerinda, S., \& Ndacyayisenga, T. (2009). Atlas of sorghum (Sorghum bicolor (L.) Moench) production in eastern and southern Africa. Univ. Nebraska-Lincoln, Lincoln NE. http://intsormil.org/scmscientificpubs/Sorghum\%20Atlas.pdf

\section{Copyright Disclaimer}

Copyright for this article is retained by the author(s), with first publication rights granted to the journal.

This is an open-access article distributed under the terms and conditions of the Creative Commons Attribution license (http://creativecommons.org/licenses/by/4.0/). 